\title{
柱状プレキャストコンクリートの製造過程における強度管理手法 METHOD OF QUALITY CONTROL AT PRODUCTION PROCESS OF PRECAST CONCRETE COLUMN
}

\author{
杉山 央*，水戸健介**
}

Hisashi SUGIYAMA and Kensuke MITO

\begin{abstract}
The strength of precast concrete is tested at production process with the test specimen made by the same curing method as an actual precast concrete element. However, the temperature history of precast concrete column with the large cross sectional size is different from that of test specimen. The difference in temperature history causes the difference of strength development between the two. The purpose of this study is to propose new types of test specimens cured under the same temperature conditions with the actual precast concrete column. The test specimens are covered with insulation and formwork according to the position in the precast concrete column.
\end{abstract}

Keywords : Precast concrete, Heat curing, Temperature history, High-strength, Heat conduction, Heat transfer プレキャストコンクリート，加熱養生，温度履歴，高強度，熱伝導，熱伝達

\section{1.はじめに}

プレキャストコンクリート（以降、PCaと略記）による工法は、 部材の高品質化、工期短縮など様々な利点を有している。このた め、従来からの床や壁などのPCa部材に加えて、近年では柱や梁な どのPCa化も進んでいる。また、高層・大型建築物に適用するた め、高強度コンクリートを使用したPCa部材も増えている。

日本建築学会建築工事標準仕様書・同解説JASS 10 プレキャスト 鉄筋コンクリート工事 $2013^{1)}$ （以降、JASS 10 と略記）に規定され ているように、 $\mathrm{PCa}$ 部材は製造工程上の脱型時、出荷日および保証 材齢において、それぞれ所要の強度を満足する必要がある。JASS 10では所要の強度を満足したかどうかの確認試験（以降、強度管 理と表記）には、(1)PCa部材と同じコンクリートで作製し、PCa部 材と同じ雰囲気温度（周囲の温度）中で養生したコンクリート供試 体（以下、PCa部材同一養生供試体と表記）、(2)PCa部材の温度履 歴と類似の温度履歴を与えて養生したコンクリート供試体（以下、 $\mathrm{PCa}$ 部材温度追従盖生供試体と表記）、(3) PCa部材から採取したコ ア供試体、(4)標準養生供試体のいずれかを用いることとしている。 しかし、それぞれについて、次のような問題がある。

1） $\mathrm{PCa}$ 部材同一養生供試体は、図1に示寸ように $\mathrm{PCa}$ 部材と同じ雰 囲気温度中で養生するが、必ずしも $\mathrm{PCa}$ 部材と同じ温度を履歷し ない。すなわち、柱状 $\mathrm{PCa}$ 部材のように部材厚が大きいと、 $\mathrm{PCa}$
部材同一養生供試体よりもセメント水和熱を内部蓄積する傾向が 顕著であり、これによって両者に温度履歴の差異が生じる ${ }^{2)}$ 。特 に、単位セメント量の大きな高強度コンクリートを使用した場合 は、 $\mathrm{PCa}$ 部材と $\mathrm{PCa}$ 部材同一養生供試体の温度履歴の差異は大き くなり ${ }^{2)}$ 、両者の強度差も無視できなくなる ${ }^{3)}{ }^{4)}$ 。

2）PCa部材温度追従養生として、JASS 10では、断熱材で作製した 養生箱内に円柱供試体を入れ、セメント水和熱による温度上昇を

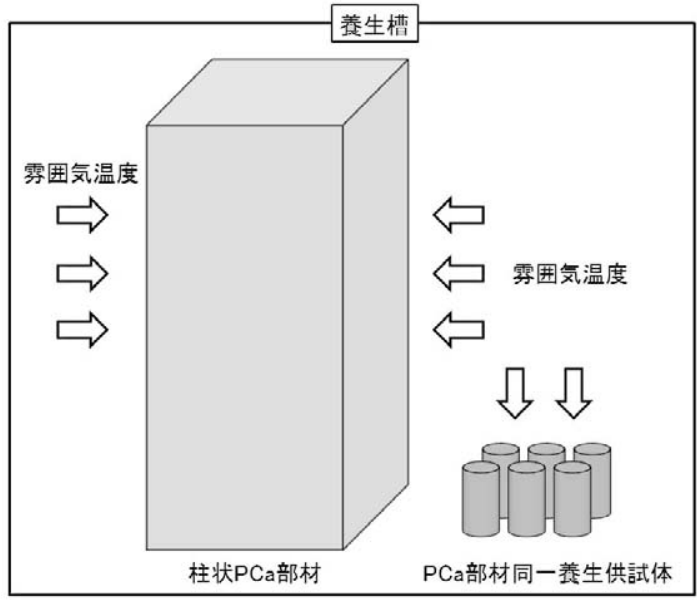

図1 PCa部材同一養生供試体を用いた強度管理方法
* 宇都宮大学大学院工学研究科 教授 $\cdot$ 博士 (工学)

** 宇都宮大学大学院工学研究科 大学院生・博士前期課程
Prof., Graduate School of Engineering, Utsunomiya Univ., Dr. Eng. Graduate Student, Graduate School of Engineering, Utsunomiya Univ. 


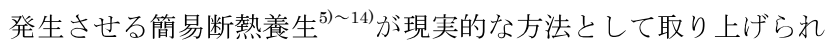
ている。しかし、簡易断熱養生では供試体の全面が断熱材で覆わ れるため、雾囲気条件（外気温、加熱養生等）が反映されない。 また、特別な養生装置を用いて、PCa部材と同じ温度を装置内の 供試体に履歴させる温度追従養生も考えられるが、一日に多種類 のPCa部材を製造することも多く、これに対応する台数の装置を 準備することは困難である。

3） PCa部材からコア供試体を採取することは、製品に欠損を生じさ せることになるので現実には難しい。

4）標準養生供試体を用いる場合は、PCa部材と標準養生供試体の 強度差を勘案した判定基準を定める必要がある。この強度差を求 めるためには、PCa部材を模擬した大型試験体を作製し、その試 験体より採取したコア供試体の強度を調べる等の実験が必要であ る。これには多大な労力、時間、費用がかかる。

JASS 10では、PCa部材と強度管理用供試体の間で発生する強度 差を判定基準に加味した上で、上記の強度管理方法を定めている。 現行の実務はこれに従って運用されているが、今後は $\mathrm{PCa}$ 部材の形 状、寸法、強度レベル等の多様化に対応した簡便で的確な強度管理 方法の提案が望まれる。また、柱状PCa部材においては、脱型時で は表面部の強度が重要になり、保証材齢では中央部および表面部の 両方の強度が重要になる等、一つのPCa部材であっても対象とする 部位に応じた強度管理が必要となる。

このような背景から、本研究では柱状 $\mathrm{PCa}$ 部材を対象として、簡 便な方法により $\mathrm{PCa}$ 部材と同じ温度を履歴させた供試体による新た な強度管理方法を検討した。すなわち、コンクリートの強度発現は 練混ぜ時からの温度履歷と密接な関係があり、同じ温度を履歴すれ ば同じ強度になるという性状に基づき、特殊な装置等を用いること なく、コンクリート円柱供試体の周囲を断熱材や型枠で覆うことに より $\mathrm{PCa}$ 部材の各部位の温度を履歴させることを意図した $\mathrm{PCa}$ 部材 モデル養生供試体による強度管理方法を提案する。

\section{2. $\mathrm{PCa}$ 部材モデル養生供試体 $S$ の提案}

\subsection{PCa 部材モデル養生供試体 S の概要}

一般に、 $\mathrm{PCa}$ 部材のコンクリート強度は、 $\mathrm{PCa}$ 部材から切り取っ たコア供試体の強度で代表される。そこで、図2に示すようにPCa 部材内に存在するコア供試体を想定し、円柱供試体の側面部を断熱

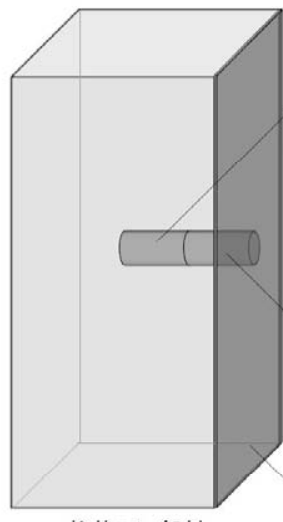

柱状PCa部材

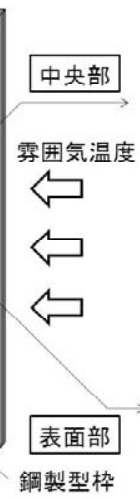

鋼製型枠

図2

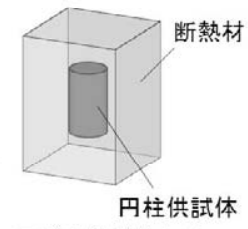

モデル供試体S-A

鋼製型枠

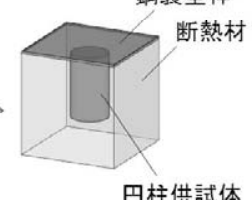

玉デル供試体S-B
材で覆い、両端面に断熱材や型枠を配置することで、PCa部材と同 じ温度を円柱供試体に履歴させることを意図としたPCa部材モデル 養生供試体 $\mathrm{S}$ （以降、モデル供試体 $\mathrm{S}$ と略記）を考案した。なお、 ここでは円柱供試体を1つずつ養生する手法を提示しているため、 $\mathrm{S}$ (single) という記号を用いた。

表1にモデル供試体 $\mathbf{S}$ の種類および概要を、図3にモデル供試体 $\mathrm{S}$ の 形状および寸法を示す。 S-Aは柱状PCa部材の中央部コアを想定して おり、円柱供試体の周囲を断熱材で覆うことでセメント水和熱を蓄 積させ、円柱供試体の温度を上昇させることを考えた。S-Bは柱状 $\mathrm{PCa}$ 部材の表面部コアを想定しており、円柱供試体の側面および一 方の端面には断熱材を、他方の端面には鋼製型枠（厚さ $6 \mathrm{~mm}$ ）を配 置した。表 2 に使用した断熱材の種類を示す。いずれも厚さ $100 \mathrm{~mm}$ の市販の発泡プラスチック系断熱材である。なお、表中の熱伝導率 および而熱温度はメーカーの仕様として示されている数值である。 この中で熱伝導率が小さく、耐熱温度が高い断熱材 $\alpha$ を使用するこ とを基本とした。比較のため、断熱材 $\beta$ および $\gamma$ を使用したS-Aも作 製し、それらはS-A $(\beta)$ およびS-A $(\gamma)$ と表記した。コンクリートを 簡易鋼製型枠（側板の厚さ $0.13 \mathrm{~mm}$ 、底板の厚さ $1.6 \mathrm{~mm}$ ）に打ち込 み、上面を塩化ビニルフィルムで密封した上で、所定の断熱材内部 に設置した。

モデル供試体 $\mathrm{S}$ との比較のため、 $\mathrm{PCa}$ 部材同一養生供試体（以降、 部材同一と略記）も作製した。

\section{2 実験概要}

\section{（1）コンクリートの使用材料および調合}

コンクリートに使用したセメントは普通ポルトランドセメント (密度 : $3.16 \mathrm{~g} / \mathrm{cm}^{3}$, 比表面積 : $3310 \mathrm{~cm}^{2} / \mathrm{g}$ ) 、細骨材は大井川産川 砂（表乾密度 : $2.56 \mathrm{~g} / \mathrm{cm}^{3}$, 吸水率 : $1.79 \%$ ）、粗骨材は青梅産砕石
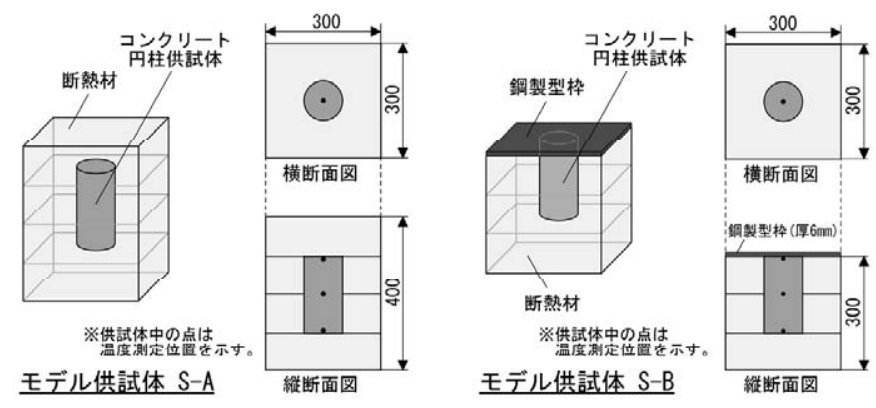

図3 PCa部材モデル養生供試体Sの形状および寸法

表1 PCa部材モデル養生供試体Sの種類および概要

\begin{tabular}{c|c|c|c|c}
\hline \multirow{2}{*}{ 記号 } & \multirow{2}{*}{ 想定している部位 } & \multicolumn{3}{|c}{ 養生時の境界条件 } \\
\cline { 3 - 5 } & & 上面 & 下面 & 側面 \\
\hline S-A & 柱状PCaの中央部 & 断熱材 $(\alpha)$ & 断熱材 $(\alpha)$ & 断熱材 $(\alpha)$ \\
\hline$S-B$ & 柱状PCaの表面部 & 鋼製型枠 & 断熱材 $(\alpha)$ & 断熱材 $(\alpha)$ \\
\hline $\mathrm{S}-\mathrm{A}(\beta)$ & 柱状PCaの中央部 & 断熱材 $(\beta)$ & 断熱材 $(\beta)$ & 断熱材 $(\beta)$ \\
\hline $\mathrm{S}-\mathrm{A}(\gamma)$ & 柱状PCaの中央部 & 断熱材 $(\gamma)$ & 断熱材 $(\gamma)$ & 断熱材 $(\gamma)$ \\
\hline
\end{tabular}

表2 使用した断熱材の種類

\begin{tabular}{c|c|c|c}
\hline 記号 & 種類 & $\begin{array}{c}\text { 熱伝導率 } \\
(\mathrm{W} / \mathrm{m} \cdot \mathrm{K})\end{array}$ & 耐熱温度 $\left({ }^{\circ} \mathrm{C}\right)$ \\
\hline$\alpha$ & 押出法ポリスチレンフォーム $\mathrm{A}$ & 0.028 & 120 \\
\hline$\beta$ & 押出法ポリスチレンフォーム $\mathrm{B}$ & 0.040 & 120 \\
\hline$\gamma$ & ビーズ法ポリスチレンフォーム & 0.040 & 80 \\
\hline
\end{tabular}


（表乾密度 : $2.66 \mathrm{~g} / \mathrm{cm}^{3}$, 吸水率 : $0.57 \%$ ）である。コンクリートの 調合を表 3 に示す。なお、モデル供試体 $\mathrm{S}$ の温度履歷と過去のPCa柱 試験体（断面寸法 $600 \times 600 \mathrm{~mm}$ の柱状PCa部材を横置きで製造した 状況を模擬）の温度測定結果 ${ }^{2}$ を比較検討することを意図し、PCa柱 試験体 ${ }^{2}$ に用いたコンクリートと同じ調合とした。

\section{（2）養生条件}

PCa部材の製造においては、一般的に加熱養生を行うが、高強度 コンクリートを使用する場合などは加熱養生を行わないこともあ る。このため、加熱養生しないシリーズ（恒温恒湿室内で、温度 $20^{\circ} \mathrm{C}$ 一定および湿度 $60 \% \mathrm{RH}$ 一定の雾囲気条件で養生）および加熱養 生するシリーズ（プログラム式チャンバー内で、図4に示すパターン の温度および湿度の雰囲気条件で加熱養生）を計画した。なお、強

表3 コンクリートの調合

\begin{tabular}{c|c|c|c|c|c|c|c}
\hline \multirow{2}{*}{ 記号 } & \multirow{2}{*}{\begin{tabular}{c} 
W/C \\
\cline { 3 - 7 }
\end{tabular}} & \multicolumn{4}{|c|}{ 単位量 $\left(\mathrm{kg} / \mathrm{m}^{3}\right)$} & 混和剤 $(\mathrm{C} \times \%)$ \\
\cline { 3 - 8 } & $\mathrm{W}$ & $\mathrm{C}$ & $\mathrm{S}$ & $\mathrm{G}$ & $\mathrm{Ad} 1 \% 1$ & $\mathrm{Ad} 2{ }^{* 1}$ \\
\hline $\mathrm{N} 33$ & 33.3 & 160 & 480 & 824 & 954 & 1.0 & 0.1 \\
\hline
\end{tabular}

※1 Ad1 : 高性能AE減水郕, ※2 Ad2 : 空気量調整剤 (消泡剤)

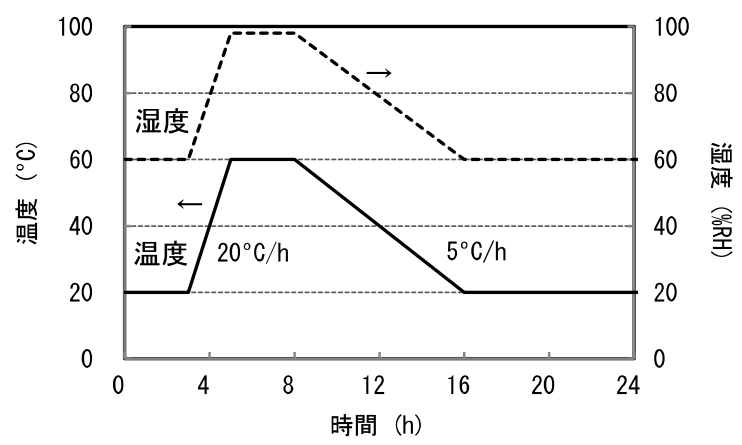

図4 加熱養生パターン
度の比較を目的として、標準養生供試体も作製した。

\section{(3) 温度測定}

既出の図3に示したように円柱供試体の上部、中心部、下部の3か 所にT型熱電対を埋め込んで温度を測定した。この円柱供試体内の温 度測定位置は、供試体の種類を表す記号の末尾に（）を付して表 記する。また、供試体近傍の気温（䨌囲気温度）も測定した。温度 測定はコンクリート打込み直後に開始し、以降 10 分間隔で材齢 3 日ま で行った。

\section{3 実験結果}

\section{(1) モデル供試体 $S$ の温度測定結果}

図5、図6および図7に加熱養生しない場合の各供試体の温度測定結 果をそれぞれ示す。最高温度が大きい順にS-A、S-B、部材同一であ り、断熱材で覆った面が多い供試体ほど温度上昇量が大きいことが わかる。また、S-Bでは上面と下面の境界条件が異なるため、供試体 内で温度差が生じており、上部は中心部および下部よりも温度が低 くなった。

図8、図9および図10に加熱養生した場合の各供試体の温度測定結 果をそれぞれ示す。S-Bおよび部材同一では、加熱養生の影響を受 け、急激な温度上昇を示した。S-Aは全面が断熱材で覆われている が、少なからず加熱養生の影響を受けており、加熱なしの場合より も高い最高温度を示した。

図11にS-Aの断熱材種類の違いによる温度履歴の比較を示す。熱 伝導率の小さな断熱材を用いた方が温度上昇量が大きいことがわか

る。なお、写真1に本実験で作製したモデル供試体 $\mathrm{S} の$ 外観を示す。

(2) PCa 柱試験体との温度比較

図12および図13に加熱養生しない場合のモデル供試体 $\mathrm{S}$ とCa柱 試験体 ${ }^{2)}$ の温度上昇量の比較を示す。なお、図中ではPCa柱試験体を PCa柱と略記している。また、それぞれ打込み温度に違いがあるた

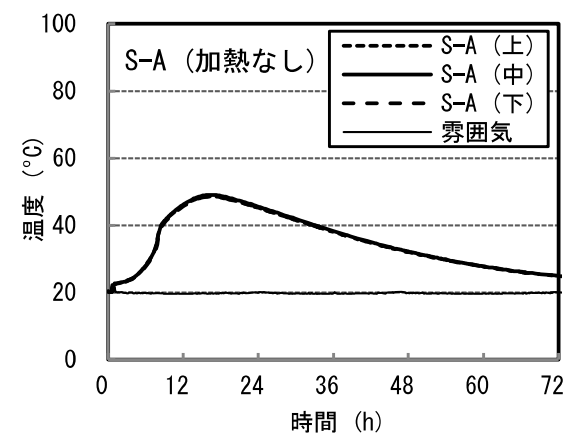

図5Ｓ-Aの温度測定結果（加熱なし）

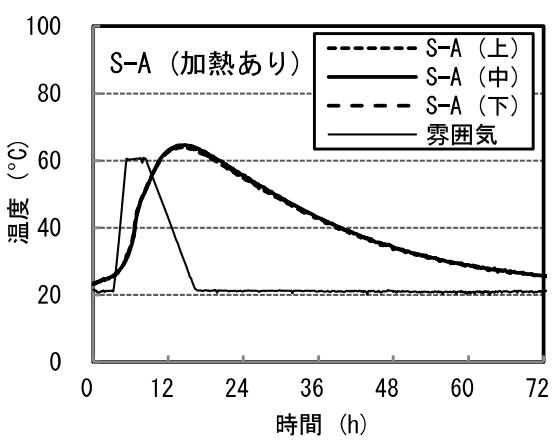

図8 S-Aの温度測定結果（加熱あり）

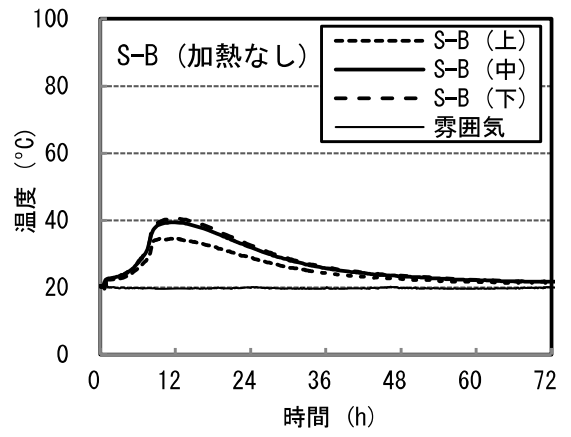

図6 S-Bの温度測定結果（加熱なし）

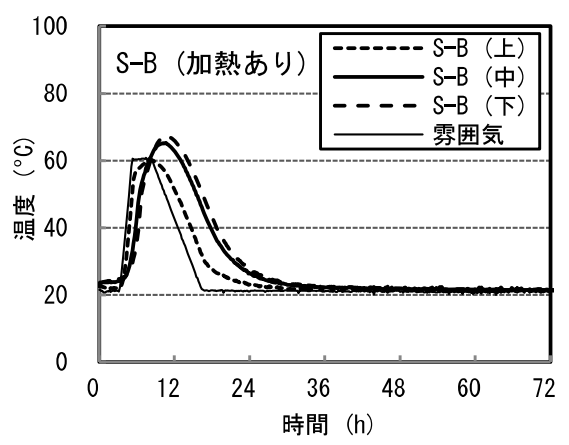

図9－Bの温度測定結果（加熱あり）

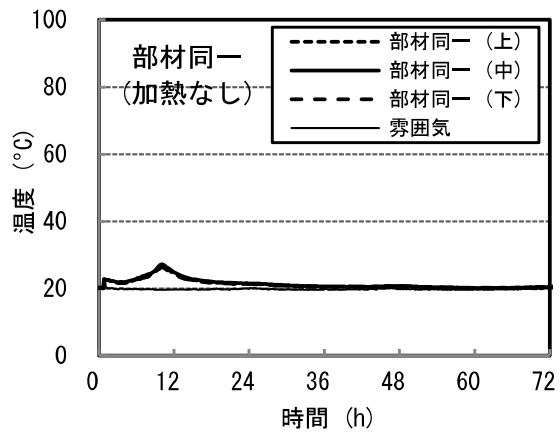

図7部材同一の温度測定結果（加熱なし）



図10 部材同一の温度測定結果（加熱あり） 


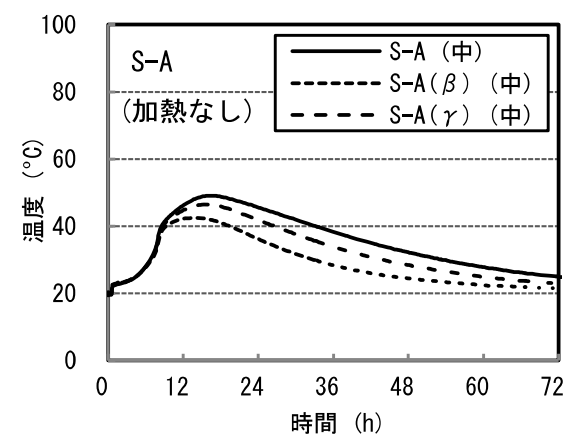

図11断熱材種類の違いによる温度比較

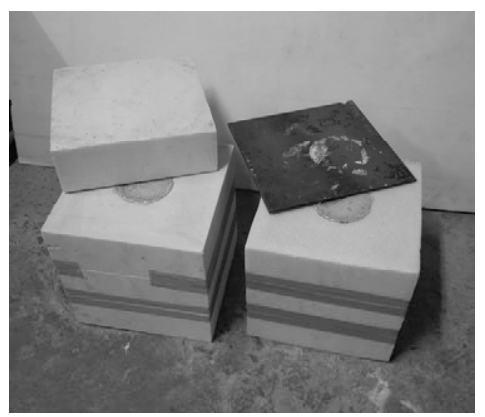

写真1 PCa部材モデル養生供試体Sの実例

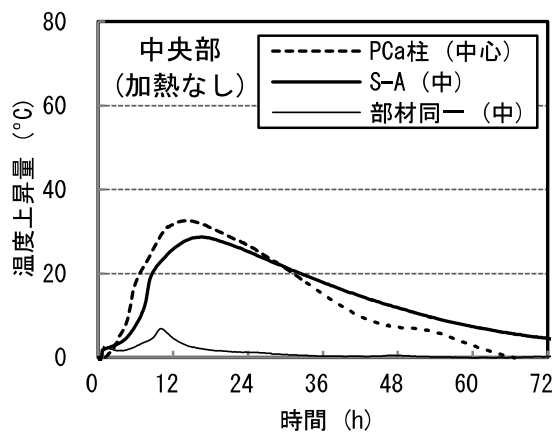

図12 S-AとPCa柱の温度上昇量 (加熱なし)

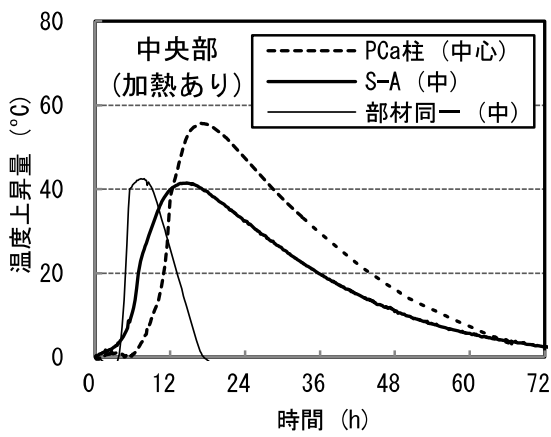

図14 S-AとPCa柱の温度上昇量(加熱あり)

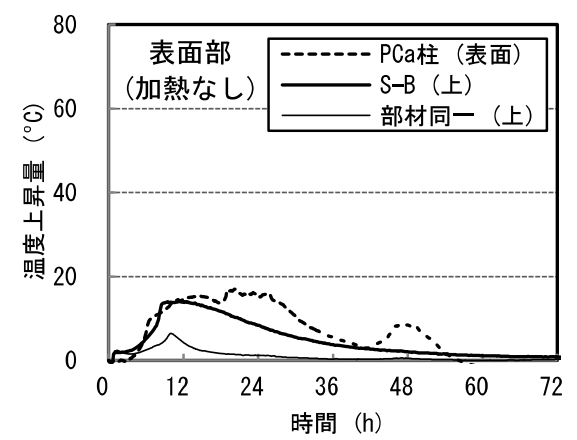

図13 S-BとPCa柱の温度上昇量 (加熱なし)

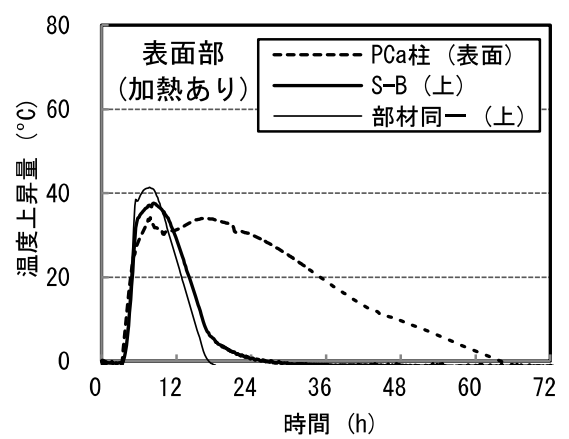

図15Ｓ-BとPCa柱の温度上昇量 (加熱あり)
め、ここでは打込み温度を起点とした温度上昇量を尺度として比較 を行った。部材同一はわずかな温度上昇しか示さないものの、 $\mathrm{PCa}$ 部材の中央部をモデル化したS-A 試験体と同じような温度上昇特性であった。PCa部材の表面部をモ デル化したS-BもPCa柱試験体と同じような温度上昇特性を示した。

図14および図15に加熱養生した場合のモデル供試体S と PCa柱試験 体 $^{2)}$ の温度上昇量の比較を示す。部材同一は加熱養生の影響を大きく 受け、PCa柱試験体の中心部および表面部とは異なる温度履歴を示 した。S-Aは、部材同一よりもPCa柱試験体に類似した温度履歴を示 したが、全面が断熱材で覆われているため、加熱養生による熱が十 分に伝わらず、PCa柱試験体に比べて温度上昇量が小さくなった。 S-Bでは、PCa柱試験体に比べて温度下降が急であった。PCa柱試験 体の表面部は、加熱養生の影響が大きいものの、内部のセメント水 和熱蓄積により高温の状態がしばらく継続する傾向が見られるが、 モデル供試体Sでは、この傾向を再現することはできなかった。

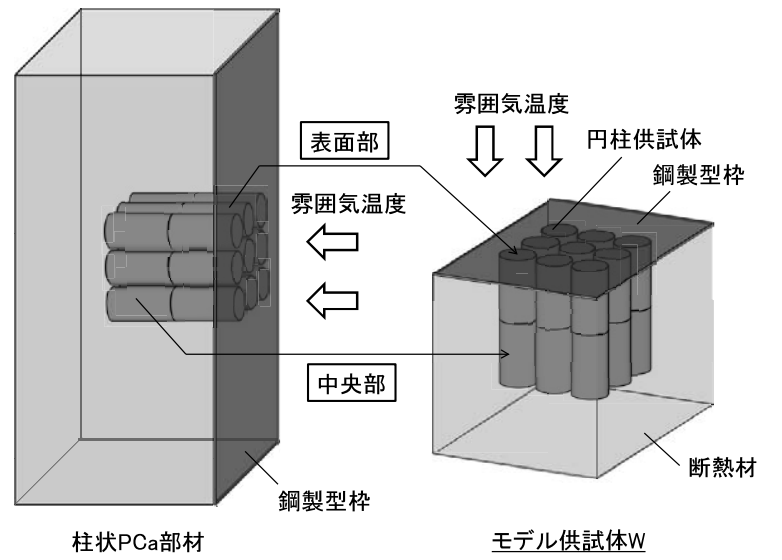

図16 PCa部材モデル養生供試体Wの概念
3. PCa 部材モデル養生供試体 W の提案

3. $1 \mathrm{PCa}$ 部材モデル養生供試体 W の概要

モデル供試体 $\mathrm{S}$ における問題点をふまえ、図16に示す新たな $\mathrm{PCa}$ 部材モデル養生供試体 $\mathrm{W}$ （以降、モデル供試体Wと略記）を考案し

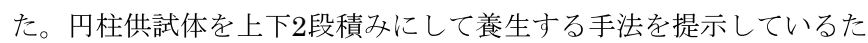
め、W（double）という記号を用いた。簡易断熱養生では供試体を 複数個入れることで温度上昇量が大きくなるとの研究報告 ${ }^{10)}$ を参考 にして、モデル供試体 $\mathrm{S}$ の1段積みから 2 段積みとし、かつ1段あたり の供試体数を 9 個とした計 18 個の供試体を断熱材内部に配置すること で、セメント水和熱による温度上昇特性を実際のPCa部材に近づけ ることを考えた。

モデル供試体Wの有用性を調べるため、まずは外側の供試体を覆 う断熱材の厚さを $100 \mathrm{~mm}$ としたモデル供試体W100について実験を 計画した。モデル供試体W100の形状および、法を図17に示す。上部 に鋼製型枠を配置することで、上段の供試体（No.1～9）はPCa部材

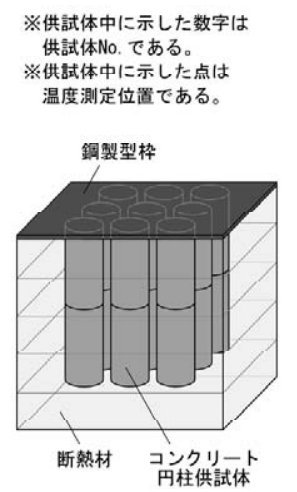

玉デル供試体 W-100

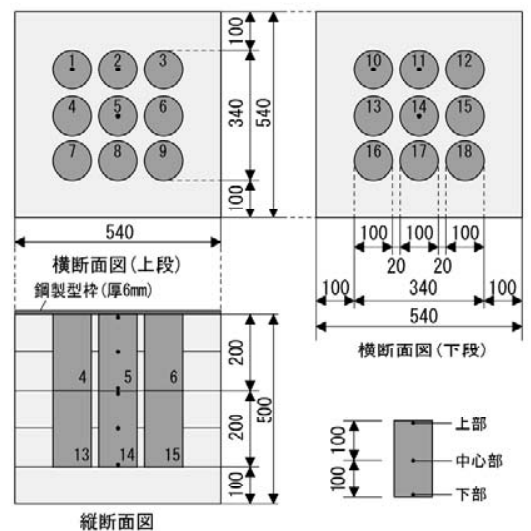

図17 PCa部材モデル養生供試体W100の形状および寸法 
の表面部コアを、下段の供試体（No.10～18）はPCa部材の中央部 コアをモデル化しており、柱状 $\mathrm{PCa}$ 部材の表面部および中央部の温 度履歴を同時に再現させることを意図した。ここで、表面部とは外 気と接寸る表層部のような特定のポイントを想定しているのではな く、表層部から梁さ $200 \mathrm{~mm}$ 程度までの表面付近を想定したものであ る。同じく、中央部とは柱状PCa部材の中心部を想定しているので はなく、中央付近の内部部分を想定したものである。 $\mathrm{PCa}$ 部材は製 造工程上の脱型時、出荷日および保証材齢において、それぞれ強度 管理を行う必要があるが、上段および下段の供試体をそれぞれ3個ず つ強度試験に用いることを意図している。なお、断熱材には既出の 表 2 における断熱材 $\alpha$ を使用した。

\section{2 実験概要}

（1）コンクリートの使用材料および調合

コンクリートには、2.2(1)に示した材料に加えて、ノルウェー産シ リカフューム（密度 : $2.2 \mathrm{~g} / \mathrm{cm}^{3}$, 比表面積 : $200000 \mathrm{~cm}^{2} / \mathrm{g}$ ) を使用し た。コンクリートの調合を表4に示す。コンクリート種類による温度 履歴の違いをモデル供試体Wにより再現できるかどうかを調心゙るた め、N18、N33およびN40の3種類の調合を計画した。

\section{（2）養生条件}

養生条件は、2.2(2) と同じである。

$$
\text { 表4 コンクリートの調合 }
$$

\begin{tabular}{|c|c|c|c|c|c|c|c|c|c|}
\hline \multirow{2}{*}{ 記号 } & \multirow{2}{*}{$\begin{array}{c}W / B^{* 1} \\
(\%)\end{array}$} & \multicolumn{5}{|c|}{ 単位量 $\left(\mathrm{kg} / \mathrm{m}^{3}\right)$} & \multicolumn{3}{|c|}{ 混和剂 $(B \times \%)$} \\
\hline & & W & c & $S F^{* 2}$ & S & $G$ & $\mathrm{Ad} 1^{\circledast 3}$ & $\mathrm{Ad} 2{ }^{\circledast 4}$ & $\mathrm{Ad} 3{ }^{* 5}$ \\
\hline N18 & 18.0 & 163 & 853 & 85 & 570 & 790 & - & - & 1.4 \\
\hline N33 & 33.3 & 160 & 480 & - & 824 & 954 & 1.0 & 0.1 & - \\
\hline N40 & 40.0 & 160 & 400 & - & 872 & 972 & 1.0 & \begin{tabular}{|l|}
0.1 \\
\end{tabular} & - \\
\hline
\end{tabular}

※1 B : 結合材 $(\mathrm{C}+\mathrm{SF}) ， ※ 2 \mathrm{SF}$ : シリカフューム, ※3 Ad1：高性能AE減水剤, $※ 4 \mathrm{Ad} 2$ : 空気量調整剂(消泡剂)， $※ 5 \mathrm{Ad} 3$ : 超高強度用高性能減水剂

\section{(3) 温度測定}

既出の図17に示したように円柱供試体の上部、中心部および下部 にT型熱電対を埋め込んで温度を測定した。温度測定はコンクリート 打込み直後に開始し、以降10分間隔で材齢3日まで行った。

\section{3 実験結果}

\section{（1）モデル供試体 W の温度測定結果}

図18、図19および図20に加熱養生しない場合のモデル供試体Wの 温度上昇量をそれぞれ示す。各コンクリートにおいて温度測定位置 ごとの温度上昇量を比較すると、N18、N33およびN40に共通して、 表面に近いNo.5の上部において温度上昇量が最も小さく、表面から 離れたNo.14の中心部および下部において温度上昇量が最も大きく なった。また、N18、N33およびN40を同じ温度測定位置で比較する と、No.5の上部を除き、単位セメント量が多いコンクリートほど温 度上昇量が大きくなった。これは、単位セメント量が多いほど、セ メント水和熱の蓄積に起因する温度上昇の傾向が顕著に現われたも のと考えられる。

図21、図22および図23に加熱養生した場合のモデル供試体Wの温 度上昇量をそれぞれ示す。各コンクリートの温度測定位置ごとの温 度上昇量を比較すると、加熱養生しない場合と同様にNo.5の上部に おいて温度上昇量が最も小さく、No.14の中心部および下部において 温度上昇量が最も大きくなった。温度測定位置ごとの温度上昇勾配 を比較すると、N33およびN40では、No.5の方がNo.14よりも温度 上昇勾配が急激であった。これは、表面に近いNo.5の方が加熱養生 の影響をより著しく受けたためと考えられる。既往のPCa実大試験 体の温度測定実験 ${ }^{2}$ でも同様の傾向が認められた。一方、N18では、 No.14の温度上昇勾配も急激であり、No.5 との温度上昇勾配につい ての差異は小さかった。N18、N33およびN40を同じ温度測定位置で 比較すると、加熱養生しない場合と同様に単位セメント量が多いコ

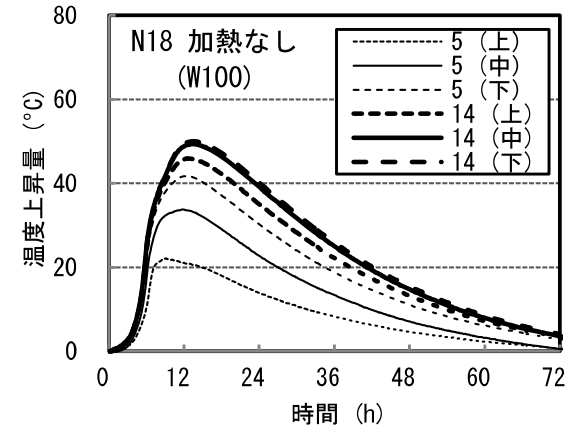

図18 W100の各部位の温度上昇量 (N18-加熱なし)

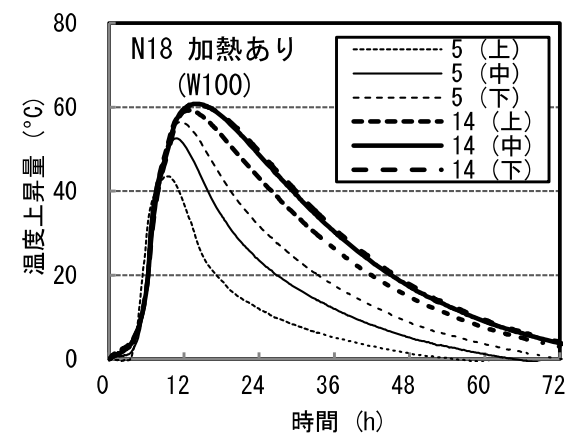

図21 W100の各部位の温度上昇量 (N18-加熱あり)

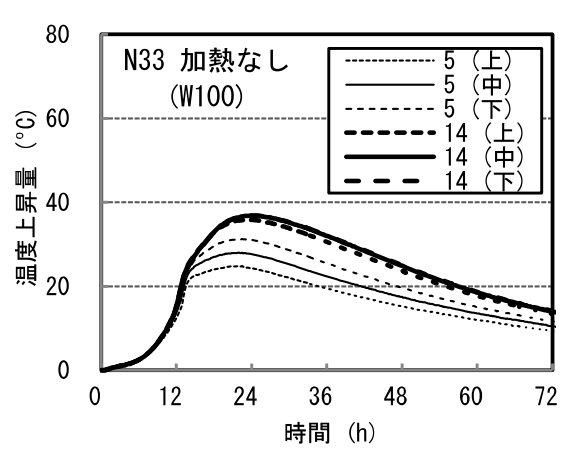

図19 W100の各部位の温度上昇量 (N33-加熱なし)

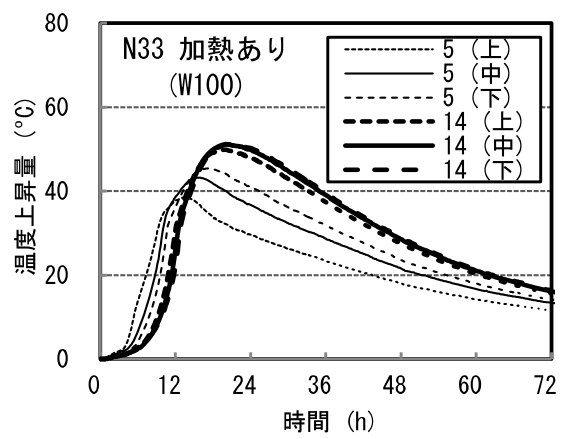

図22 W100の各部位の温度上昇量 (N33-加熱あり)

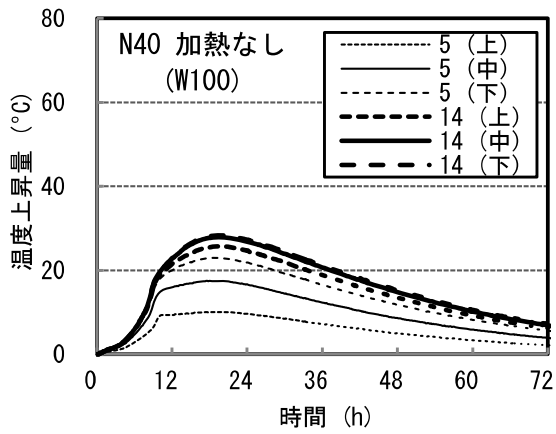

図20W100の各部位の温度上昇量 (N40-加熱なし)

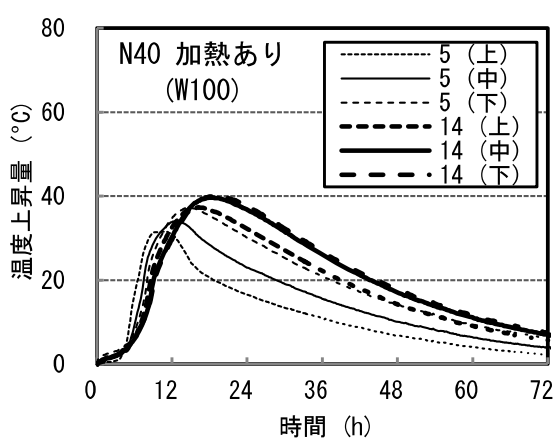

図23 W100の各部位の温度上昇量 (N40-加熱あり) 


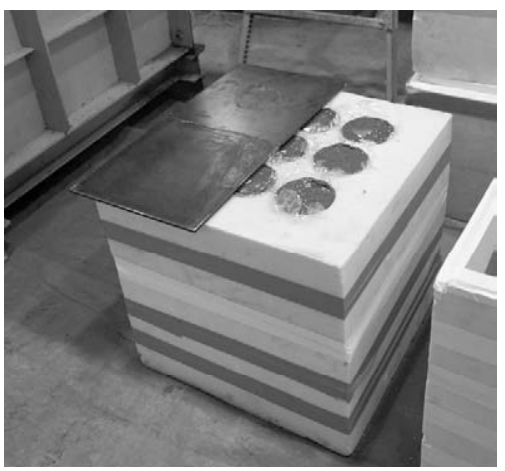

写真2 PCa部材モデル養生供試体W100の実例

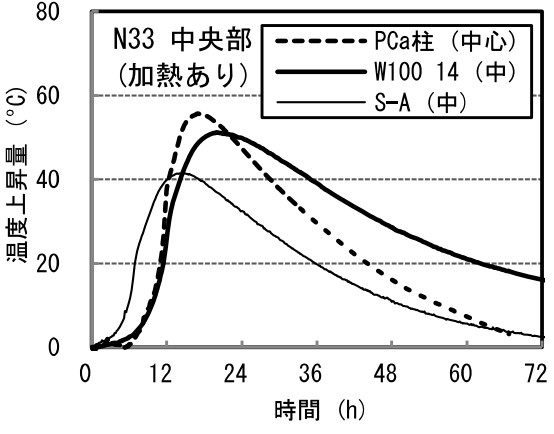

図24 W100とPCa柱の温度上昇量 (中央部)

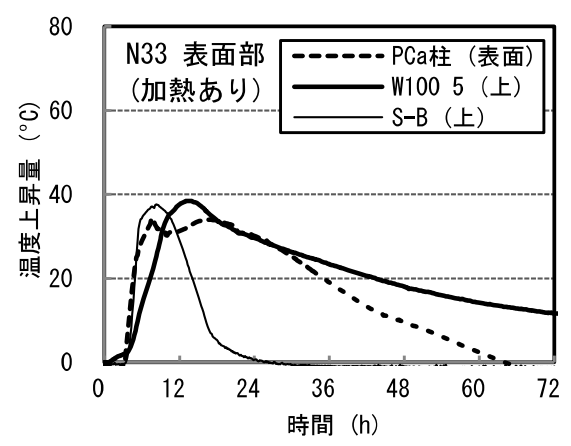

図25W100とPCa柱の温度上昇量 (表面部)
ンクリートほど温度上昇量が大きくなった。

加熱養生の有無により比較すると、各コンクリートのす心゙ての温 度測定位置において、加熱養生した方が大きな温度上昇量および急 激な温度上昇勾配を示した。表面に近いNo.5では加熱養生の影響を 直接受けるが、内部のNo.14についてもNo.5を介して加熱養生の影 響が伝わっていることがわかる。なお、写真 2 に本実験で作製したモ デル供試体W100の外観を示す。

\section{(2) $\mathrm{PCa}$ 柱試験体との温度比較}

図24に、加熱養生した場合のモデル供試体W100の中央部（No.14 の中心部）と $\mathrm{PCa}$ 柱試験体 ${ }^{2)}$ の温度上昇量の比較を示す。モデル供試 体W100はPCa柱試験体よりも若干小さな温度上昇量となったが、 $\mathrm{S}-\mathrm{A} よ り も \mathrm{PCa}$ 柱試験体に類似した温度履歴を示した。図25に、加熱 養生した場合のモデル供試体W100の表面部（No.5の上部）と $\mathrm{PCa}$ 柱試験体 ${ }^{2)}$ の温度上昇量の比較を示す。モデル供試体W100はPCa柱 試験体とほぼ同じ温度上昇量を示し、温度下降勾配についても実大 $\mathrm{PCa}$ 試験体と同様に緩やかなものとなった。すなわち、S-Bで見られ た問題点が解決できたといえる。

\section{PCa 製造工場における検証実験}

\section{1 試験体および供試体の種類}

モデル供試体Wの有用性を検証するため、実際のPCa製造工場 （栃木県大田原市）においてモデル供試体 $\mathrm{W}$ と大型 $\mathrm{PCa}$ 柱試験体 (断面寸法 $1000 \times 1000 \mathrm{~mm}$ の柱PCa部材を縦置きで製造した状況を 模擬）の温度履歴および強度の比較実験を行った。図26に大型 $\mathrm{PCa}$ 柱試験体の形状および寸法を示す。モデル供試体Wについては、 図17に示したW100に加えて、外側の供試体を覆う断熱材の厚さが $150 \mathrm{~mm}$ およ゙200mmのモデル供試体W150およびW200も計画し た。モデル供試体W150およびW200の形状および寸法をそれぞれ 図27および図28に示す。さらに、比較のため、簡易断熱養生供試体 （以降、簡易断熱と略記）および部材同一も作製した。簢易断熱養 生箱は図 29 に示寸形状および寸法であり、既出の表 2 に示した断熱材 $\gamma$ で作製されている。また、円柱供試体どうしの隙間には断熱材 $\gamma$ と同じ素材で製造された発泡ビーズを充填した。

\section{2 実験概要}

\section{（1）コンクリートの使用材料および調合}

セメントには低発熱系セメントにシリカフュームをプレミック スしたセメント ${ }^{15)}{ }^{16)}$ (密度 : $3.04 \mathrm{~g} / \mathrm{cm}^{3}$, 比表面積 : $6170 \mathrm{~cm}^{2} / \mathrm{g}$ ) を、細骨材には福島県白河産砕砂（表乾密度 : $2.63 \mathrm{~g} / \mathrm{cm}^{3}$, 吸水率 : $2.17 \%$ ）を、粗骨材には鹿沼産砕石（表乾密度 : $2.64 \mathrm{~g} / \mathrm{cm}^{3}$, 吸水
率 : 0.74\%）を使用した。コンクリートの調合を表5に示す。

（2）コンクリートの打込みおよび養生条件

2013年10月 16 日にコンクリートの打込みを行った。打込み時の気 温は $19.5^{\circ} \mathrm{C}$ あ゙あた。練上がり後のコンクリートのスランプフロー は $63.0 \mathrm{~cm} 、$ 空気量は $1.7 \%$ 、温度は $21.0^{\circ} \mathrm{C}$ であった。コンクリート を型枠に打ち込み後、すべての試験体および供試体を 1 つのビニル シートで覆った。加熱は行わず、常温のシート養生とした。なお、 温度測定および強度試験に必要な数量を確保するため、モデル供試 体W100、W150およびW200についてはそれぞれ2セットずつ、簡易 断熱養生供試体については3セットを作製した。また、強度の比較を 目的として、標準養生供試体（以降、20Wと略記）および $20^{\circ} \mathrm{C}$ 一定 の封かん養生供試体（以降、20Sと略記）も作製した。

\section{(3) 温度測定}

大型PCa柱試験体については、既出の図26に示したa〜dの4ヶ所 にT型熱電対を埋め込んで温度を測定した。モデル供試体Wについて は、既出の図27および図28に示した位置にT型熱電対を埋め込んで

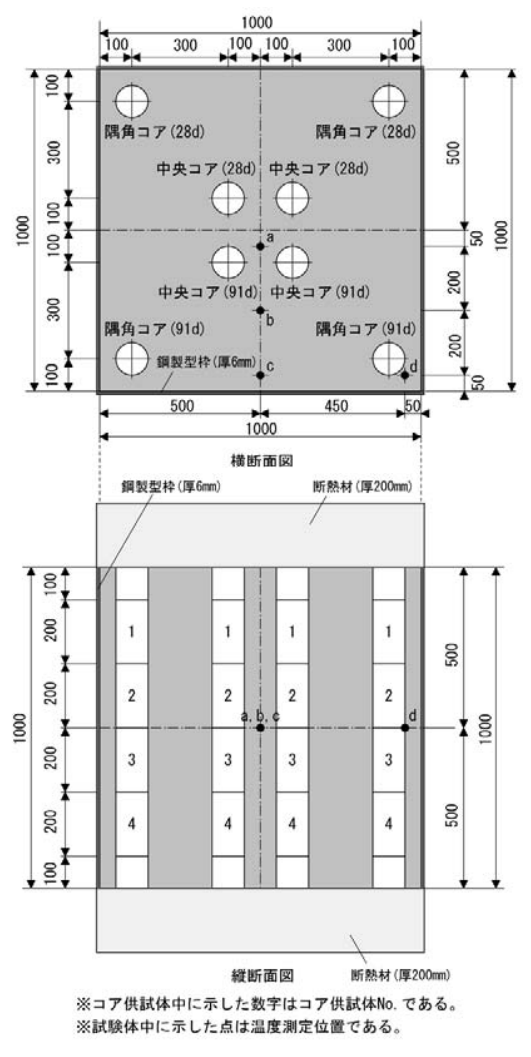

図26 大型PCa柱試験体の形状および寸法 


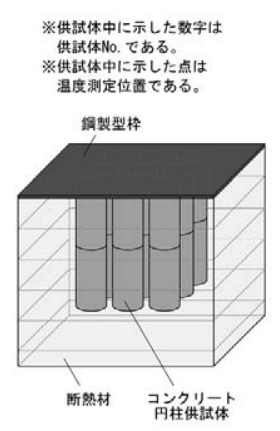

玉デル供試体 W-150

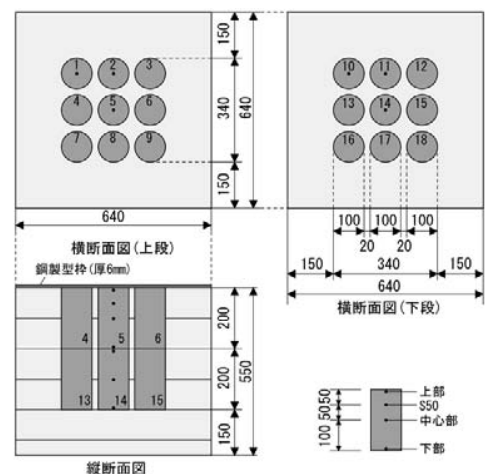

図27 PCa部材モデル養生供試体W150の形状および寸法

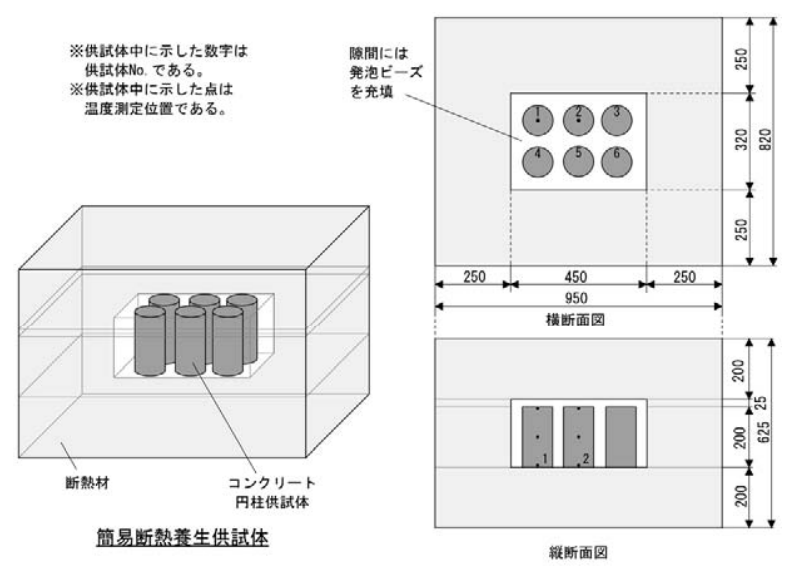

図29簡易断熱養生供試体の形状および寸法

温度を測定した。上段の供試体（No.1、2および5）については、上 面より深さ50mmの位置にも $\mathrm{T}$ 型熱電対を埋め込んだ（図27および図 28ではS50 と表記）。これは、大型PCa柱試験体の温度測定位置と整 合させるためであり、モデル供試体W100についても同様の位置で温 度を測定した。簡易断熱については、既出の図29に示したように供 試体の上部、中心部、下部の3か所にT型熱電対を埋め込んで温度を 測定した。これらの円柱供試体内の温度測定位置は、供試体の種類 を表す記号の末尾に（）を付して表記する。また、供試体近傍の 気温（䨌囲気温度）も測定した。温度測定はコンクリート打込み直 後に開始し、以降10分間隔で材齢7日まで行った。

\section{（4）圧縮強度試験}

大型PCa柱試験体については、既出の図26に示した位置からコア 供試体を採取し、材齢28および91日に圧縮強度試験を行った。各材

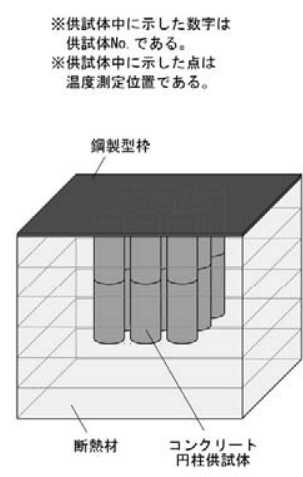

玉デル供試体 W-200

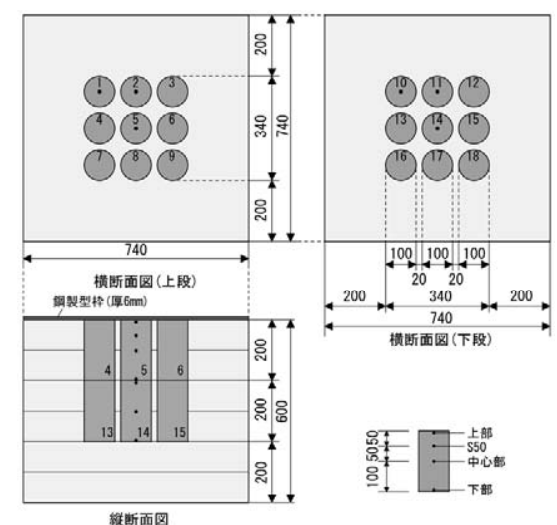

図28ＰCa部材モデル養生供試体W200の形状および寸法

表5 コンクリートの調合

\begin{tabular}{|c|c|c|c|c|c|c|}
\hline \multirow{2}{*}{ 記号 } & \multirow{2}{*}{$\begin{array}{l}\text { W/C } \\
(\%)\end{array}$} & \multicolumn{4}{|c|}{ 単位量 $\left(\mathrm{kg} / \mathrm{m}^{3}\right)$} & 混和剂 (C×\%) \\
\hline & & $\bar{W}$ & $c$ & $S$ & $\bar{G}$ & $\mathrm{Ad} 4^{* 1}$ \\
\hline SFPC18 & 18.0 & 155 & 862 & 544 & 892 & 1.5 \\
\hline
\end{tabular}

※1 Ad4; 高性能AE減水剂

表6 圧縮強度試験に用いた供試体の組み合わせ

\begin{tabular}{|c|c|c|c|c|}
\hline \multirow{2}{*}{ 種類 } & \multirow{2}{*}{ セットNo. } & \multirow{2}{*}{$\begin{array}{l}\text { 試験 } \\
\text { 材齢 }\end{array}$} & \multicolumn{2}{|c|}{ 供試体No. } \\
\hline & & & 上段 & 下段 \\
\hline \multirow{4}{*}{ モデル供試体W } & 1 & 1日 & $2,3,6$ & $11,12,15$ \\
\hline & 1 & 7日 & $4,7,8$ & $13, \quad 16,17$ \\
\hline & 1 & 28日 & $1,5,9$ & $10,14,18$ \\
\hline & 2 & 91日 & $4,7,8$ & $13,16,17$ \\
\hline \multirow{4}{*}{ 簡易断熱養生供試体 } & 1 & 1日 & \multicolumn{2}{|c|}{$1,2,3$} \\
\hline & 1 & 7日 & \multicolumn{2}{|c|}{$4,5,6$} \\
\hline & 2 & 28日 & \multicolumn{2}{|c|}{$1,2,3$} \\
\hline & 2 & 91日 & \multicolumn{2}{|c|}{$4,5,6$} \\
\hline
\end{tabular}

※ モデル供試体WはセットNo.2で、簡易断熱養生供試体はセットNo.3で温度測定を行った。

齢でNo.1〜4の4個の供試体を圧縮強度試験に用い、その平均值を試 験結果とした。各モデル供試体W、簡易断熱、部材同一、20Wおよ び20Sについては、材齢1、7、28および91日にそれぞれ3個の供試 体の圧縮強度試験を行い、その平均值を試験結果とした。なお、前 記のとおり、モデル供試体Wはそれぞれ2セットずつ作製したが、上 段および下段の熱電対を埋め込んでいない3個の供試体を圧縮強度試 験に用いた。簡易断熱養生供試体は3セットを作製したが、同じく熱 電対を埋め込んでいない3個の供試体を圧縮強度試験に用いた。圧縮 強度試験に用いた供試体の組み合わせを表 6 に示す。また、写真 $3 に$ $\mathrm{PCa}$ 製造工場における実験の状況を示す。

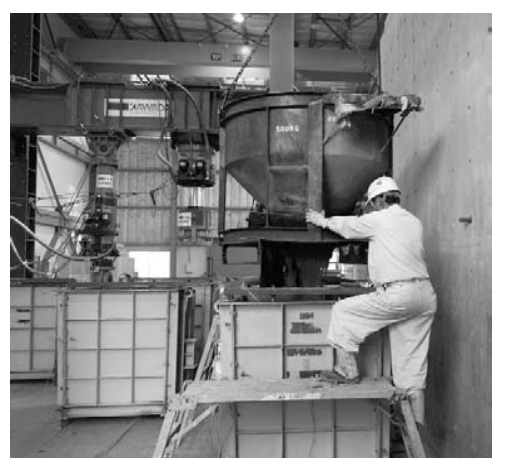

(a) 大型PCa柱試験体

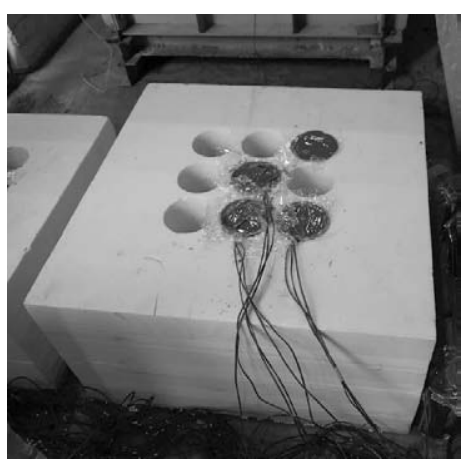

(b) PCa部材モデル養生供試体W200

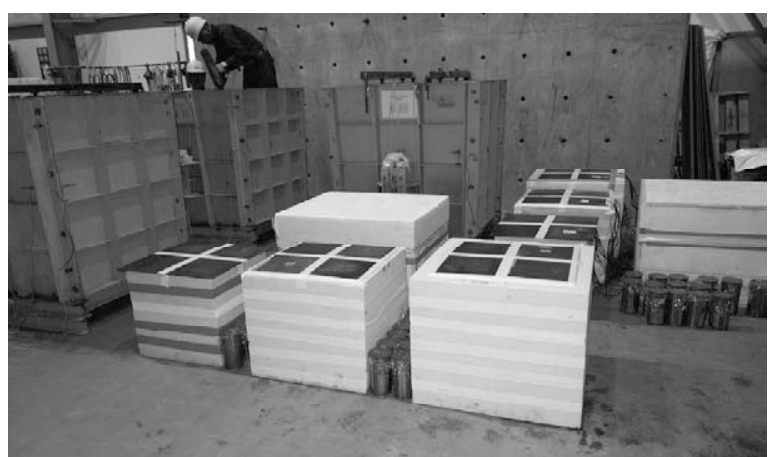

（c）コンクリート打込み後の各種試験体・供試体

写真3PCa製造工場における実験の状況 


\section{3 実験結果}

\section{（1）大型 PCa 柱試験体および各管理用供試体の温度履歴}

図30に大型 $\mathrm{PCa}$ 柱試験体の中央部およびそれに対応した各供試 体の温度測定結果を示す。大型 $\mathrm{PCa}$ 柱試験体の中央部付近ではa点 およびb点の温度測定を行ったが、モデル供試体Wの中央部である No.14の中心部（表面から深さ $300 \mathrm{~mm} ）$ と位置の近いb点を取り上 げることとした。また、簡易断熱ではNo.2の中心部、部材同一では 中心部の温度をそれぞれ取り上げた。部材同一は大型PCa柱試験体 とは明らかに異なる温度履歴であるが、各モデル供試体Wおよび簡 易断熱は大型 $\mathrm{PCa}$ 柱試験体に類似した温度履歴特性を示した。最高

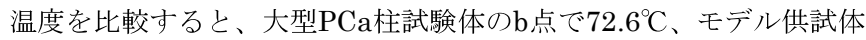
$\mathrm{W} の \mathrm{~W} 100$ で $62.4^{\circ} \mathrm{C} 、 \mathrm{~W} 150$ で $66.3^{\circ} \mathrm{C} 、 \mathrm{~W} 200$ で $64.3^{\circ} \mathrm{C}$ 、簡易断熱で $62.0^{\circ} \mathrm{C}$ 、部材同一で $25.8^{\circ} \mathrm{C}$ であった。モデル供試体Wの最高温度は 大型 $\mathrm{PCa}$ 柱試験体より低く、その差は $6.3 \sim 10.2^{\circ} \mathrm{C}$ であった。モデル 供試体Wでは供試体を断熱材で覆っているものの、大型 $\mathrm{PCa}$ 柱試験 体よりもセメント水和熱の外部への拡散傾向が著しかったことが原 因と考えられる。各モデル供試体Wで比較すると、W150の最高温度

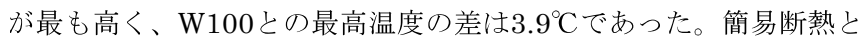
大型 $\mathrm{PCa}$ 柱試験体の最高温度の差は $10.6{ }^{\circ} \mathrm{C}$ であり、モデル供試体 $\mathrm{W}$ よりも大きな温度差となった。簡易断熱では、供試体を覆う断熱材

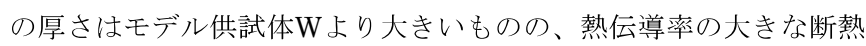
材を使用していることが原因と考えられる。

図31に大型PCa柱試験体の表面部およびそれに対応した各供試体 の温度測定結果を示す。大型 $\mathrm{PCa}$ 柱試験体の表面部c点は表面から深 さ $50 \mathrm{~mm}$ の位置にあるため、モデル供試体WではNo.5のS50を取り 上げた。部材同一では中心部の温度を取り上げた。なお、簡易断熱 は表面部を対象としたものではないため、ここでは取り上げていな い。部材同一は大型PCa柱試験体とは明らかに異なる温度履歴であ

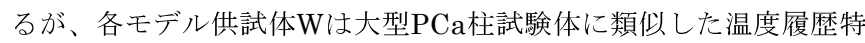
性を示した。しかし、最高温度を比較すると、大型PCa柱試験体の

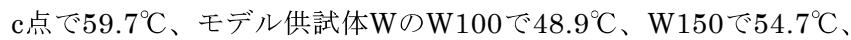
$\mathrm{W} 200$ で50.8 $8^{\circ} \mathrm{C}$ とり、中央部と同様にモデル供試体Wの最高温度は

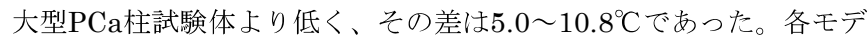
ル供試体Wで比較すると、中央部と同様にW150の最高温度が最も高 く、W100との最高温度の差は $5.8^{\circ} \mathrm{C}$ であった。

図32に大型PCa柱試験体の隅角部およびそれに対応した各供試体 の温度測定結果を示す。大型PCa柱試験体の隅角部d点と直接対応す るモデル供試体Wの部位はないが、モデル供試体Wの上段の角部に 位置するNo.1の中で、d点と同じく表面から深さ $50 \mathrm{~mm}$ の位置にある S50を取り上げた。なお、部材同一では中心部の温度を取り上げ、簡 易断熱は隅角部を対象としたものではないため取り上げなかった。 モデル供試体WのW100およびW150は、大型 $\mathrm{PCa}$ 柱試験体のd点と 類似した温度履歴特性を示した。W200では、大型PCa柱試験体、 W100およびW150に比べて温度上昇量が小さかった。本実験では、 す心゙ての試験体および供試体を 1 つのビニルシートで覆い、同じ雾 囲気温度のもとで養生することを計画したが、W200は比較的シー 卜外部の温度の影響を受けやすい設置位置であったため、温度上昇 量の差異が発生した可能性も考えられる。最高温度は、大型 $\mathrm{PCa}$ 柱

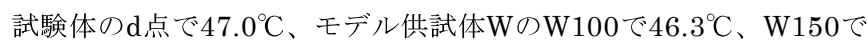
$48.9^{\circ} \mathrm{C} 、 \mathrm{~W} 200$ で $40.0^{\circ} \mathrm{C}$ であった。

（2） PCa 部材モデル養生供試体 W の内部温度差について

ここまでは、モデル供試体Wの表面部（上段）と中央部（下段） の温度を対象として鉛直方向の温度分布に着目してきたが、水平方 向の温度分布についても明らかにしておく必要がある。すなわち、 同じ表面部（上段）であるNo.1、No.2およびNo.5における温差差、 ならびに同じ中央部（下段）であるNo.10、No.11およびNo.14にお

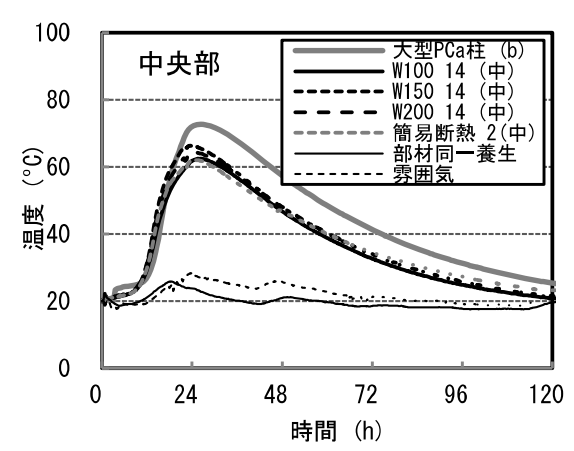

図30 PCa製造実験の温度測定結果 (中央部)

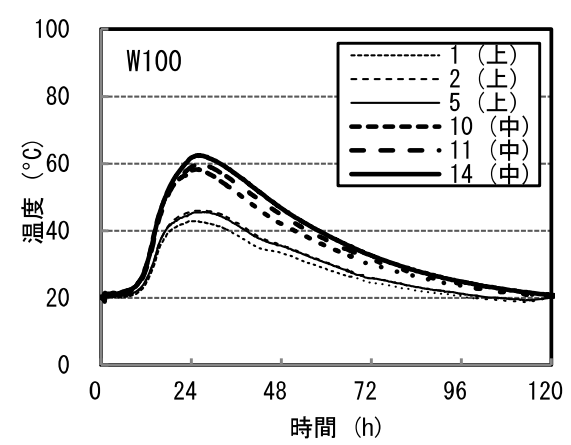

図33 水平位置の違いによる温度比較 (W100)

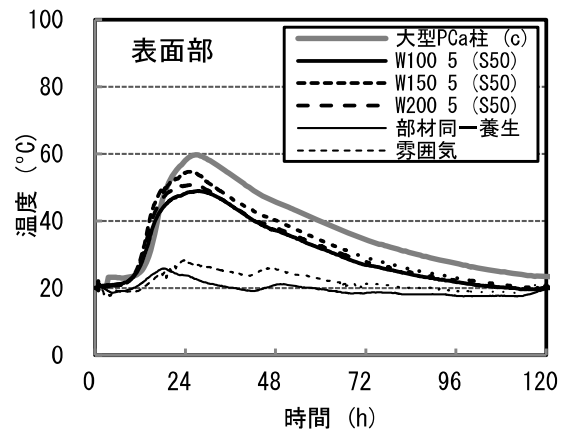

図31 PCa製造実験の温度測定結果 (表面部)

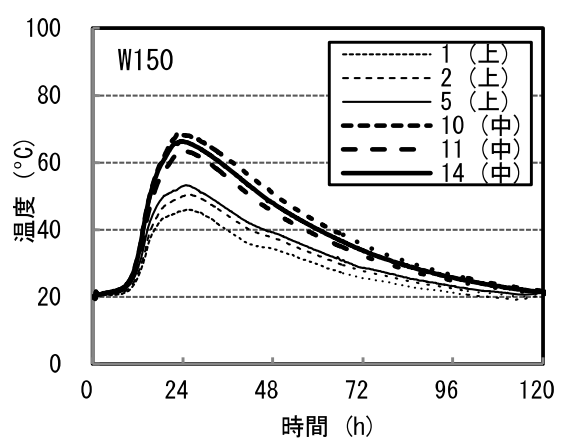

図34 水平位置の違いによる温度比較 (W150)

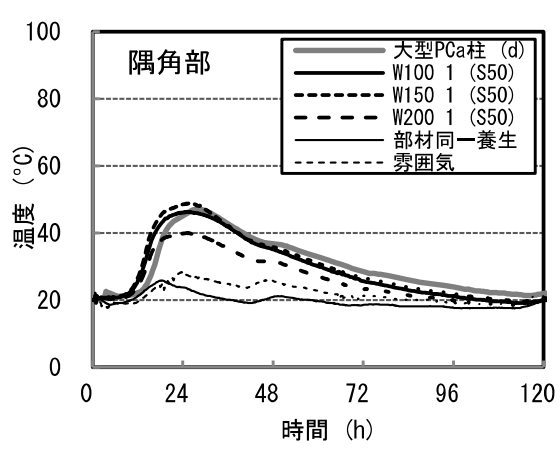

図32 PCa製造実験の温度測定結果 (隅角部)

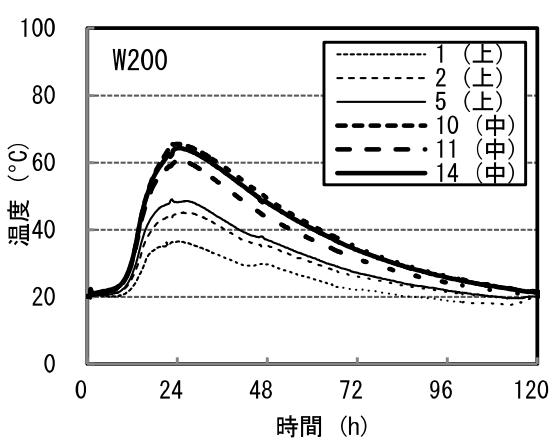

図35 水平位置の違いによる温度比較 (W200) 
ける温度差について確認した。

図33、図34および図35に、それぞれW100、W150およびW200に おける水平位置の違いによる温度履歴の比較を示す。同じ表面部で あるNo.1、No.2およびNo.5の上部であっても水平位置の違いによ り温度差が認められる。最高温度を比較すると、いずれのモデル供 試体Wにおいても上段の角部に位置寸るNo.1が最も低かった。各モ デル供試体Wの表面部における水平位置の違いによる最高温度の差 は、W100で $3.1^{\circ} \mathrm{C} 、 \mathrm{~W} 150$ で $7.4^{\circ} \mathrm{C} 、 \mathrm{~W} 200$ で $12.5^{\circ} \mathrm{C}$ であった。(1)に 記したように、W200のNo.1については設置位置による影響が現わ れた可能性も考えられる。一方、中央部についてもNo.10、No.11お よびNo.14の中心部に水平位置の違いによる温差差が認められる。各 モデル供試体Wの中央部における水平位置の違いによる最高温度の 差は、W100で $4.1^{\circ} \mathrm{C} 、 \mathrm{~W} 150$ で $5.2^{\circ} \mathrm{C} 、 \mathrm{~W} 200$ で $4.9^{\circ} \mathrm{C}$ あ゙あた。 $\mathrm{W} 150$ およびW200においては、表面部よりも最高温度の差が小さかった。 W200のNo.1を除けば、水平位置の違いによる温度履歴の差異は著し いものではないが、少なからず差があり、厳密には同一条件の管理 用供試体とはならないため、各材齢で3個の供試体を選択する際に考 慮する必要がある。

\section{（3）大型 $\mathrm{PCa}$ 柱試験体および各管理用供試体の強度特性}

図36に $\mathrm{PCa}$ 部材の中央部を対象とした各種供試体の圧縮強度を示 す。材齢1日において、モデル供試体Wおよび簡易断熱は、部材同 一、20Wおよび20Sの約2倍の強度を示した。材齢7日においても、

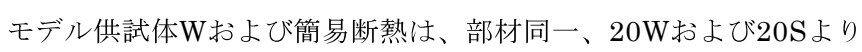
も大きな強度を示した。材齢28日では、多少の差はあるが、モデル
供試体W、簡易断熱、部材同一および20Sは、大型 $\mathrm{PCa}$ 柱試験体の コア供試体と同程度の強度であった。材齢91日では、モデル供試体 $\mathrm{W}$ は、大型 $\mathrm{PCa}$ 柱試験体のコア供試体と同程度の強度を示した。一 方、部材同一、20Wおよび20Sは、大型PCa柱試験体のコア供試体よ りも大きな強度を示した。部材同一、20Wおよび20Sは、初期材齢 に高温を履歴していないため、大型PCa柱試験体よりも長期材龄に おける強度増進が順調に進しだことにより、強度差が発生したと考 えられる。

図37にPCa部材の表面部を対象とした各種供試体の圧縮強度を示 す。なお、実験の都合上、大型 $\mathrm{PCa}$ 柱試験体の隅角部よりコア供試 体を採取しているが、ここでは表面部のコア供試体として取り扱う こととした。また、簡易断熱は表面部を対象としたものではないた め、ここでは取り上げていない。材齢1日において、モデル供試体 Wは、部材同一、20Wおよび20Sよりも大きな強度を示した。しか し、その強度差は、中央部で認められた強度差よりも小さい。これ は、表面部では中央部ほど高温にならなかったため、初期強度発現 も中央部より緩やかであったことが理由と考えられる。材龄7日にお いても、モデル供試体Wの方が、部材同一、20Wおよび20Sよりも 大きな強度を示したが、その差は材齢1日よりも小さい。材齢28日で は、モデル供試体Wおよび部材同一は、大型 $\mathrm{PCa}$ 柱試験体のコア供 試体と同程度の強度を示した。材齢91日では、モデル供試体Wは、 大型PCa柱試験体のコア供試体よりも高い強度を示した。モデル供 試体Wの中央部（下段）と表面部（上段）を比較すると、材齢91日 強度は表面部の方が大きい。これは、表面部では中央部ほど高温に

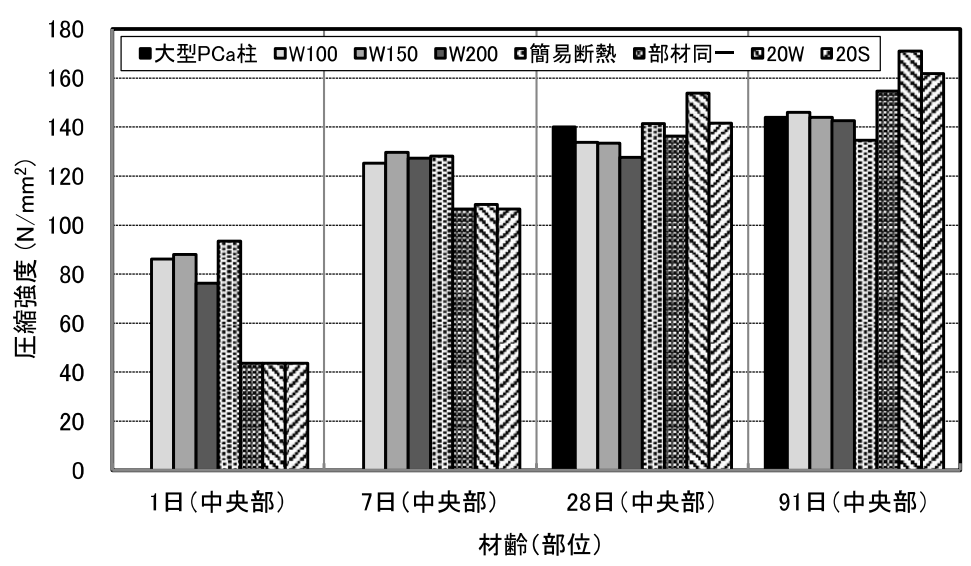

図36 PCa部材の中央部を対象とした各種供試体の圧縮強度

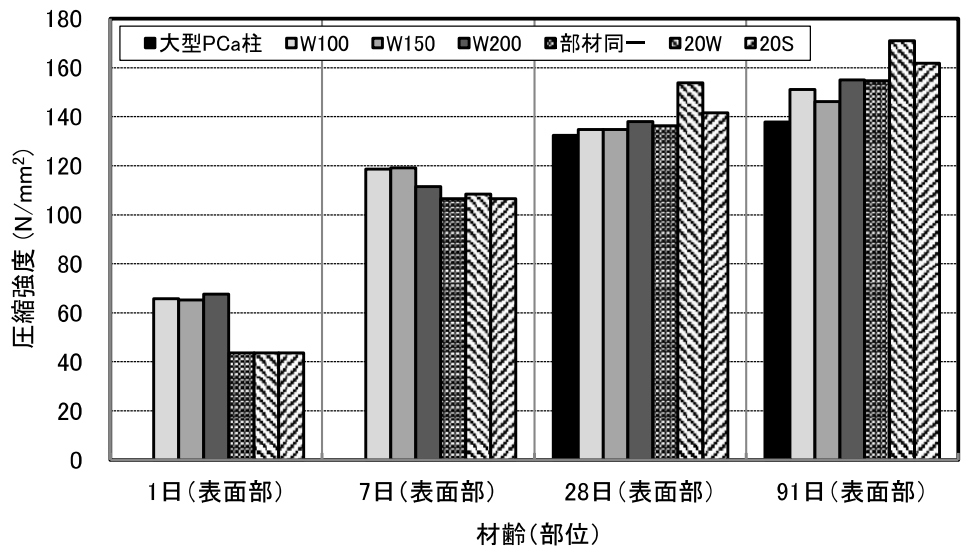

図37PCa部材の表面部を対象とした各種供試体の圧縮強度

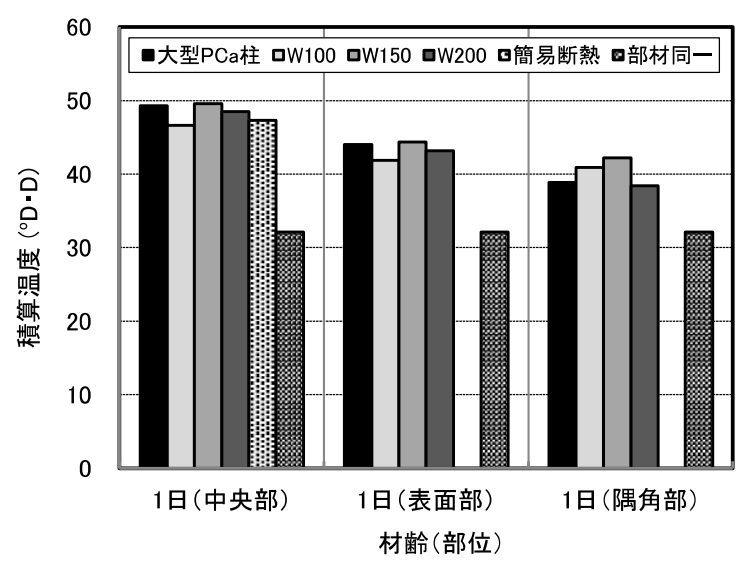

図38材齢1日における各種供試体の積算温度

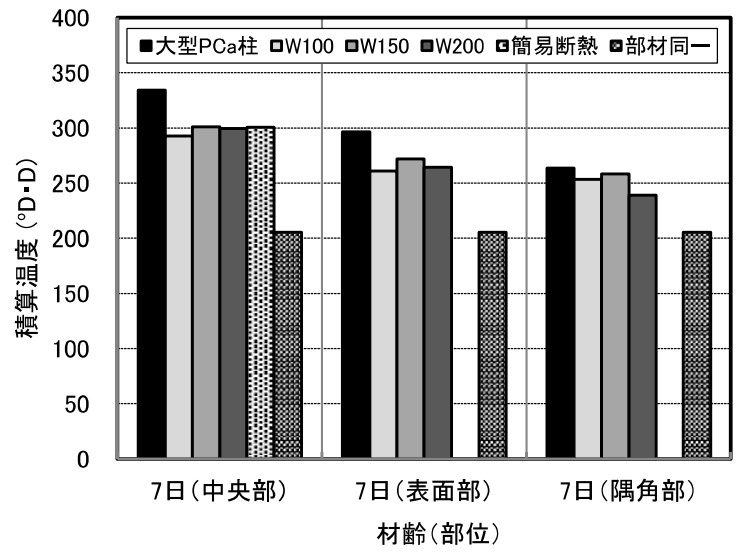

図39材齢7日における各種供試体の積算温度 
ならなかったため、長期材齢における強度増進が中央部ほど停滞し なかったことが理由と考えられる。

材齢1日および7日においては、大型PCa柱試験体からコア供試体 を採取していないため、管理用供試体との強度の比較を直接行うこ とができない。そこで、積算温度を比較することで、間接的に強度 の比較を行うこととした。既往の研究 ${ }^{4}$ では、初期材齢に限れば、温 度履歴の異なるコンクリートの強度を積算温度を指標として一律に 推定できることが示されている。図38に材齢1日における各種供試体 の積算温度を示す。なお、図38は、既出の図30、図31および図32に 示した温度測定結果から積算温度を求めたものである。中央部のモ デル供試体Wおよび簡易断熱は、大型 $\mathrm{PCa}$ 柱試験体と同程度の積算 温度である。表面部および隅角部においても、ある程度の差はある が、モデル供試体Wは大型 $\mathrm{PCa}$ 柱試験体とほぼ同程度の積算温度を 示した。いずれも積算温度が同程度であることから、モデル供試体 $\mathrm{W}$ は大型PCa柱試験体とほぼ同じ材齢1日強度を示すことが推測でき る。一方、部材同一は大型PCa柱試験体よりも小さい積算温度を示 し、強度にも差異があると考えられる。

図39に材龄7日における各種供試体の積算温度を示す。中央部のモ デル供試体Wおよび簡易断熱は、大型PCa柱試験体よりも小さな積 算温度となった。これは、(1)に示したとおり、大型PCa柱試験体よ りも低い温度履歴であったことが原因である。表面部においても、 モデル供試体 $\mathrm{W}$ は大型 $\mathrm{PCa}$ 柱試験体よりも小さな積算温度を示し た。このため、大型PCa柱試験体とはある程度の強度差が発生する 可能性がある。隅角部では、モデル供試体Wは大型PCa柱試験体と ほぼ同程度の積算温度を示した。一方、材齢1日と同様に、7日でも 部材同一は大型PCa柱試験体よりも小さい積算温度を示した。

以上より、モデル供試体Wは必ずしも大型 $\mathrm{PCa}$ 柱試験体と同一の 温度履歴および強度を示すわけではないが、大型PCa柱試験体の中 央部および表面部における温度や強度と類似した特性を示すことが 明らかになった。今後、供試体の配置等を詳細に検討するととも に、検証実験を重初ていく必要がある。また、外側の供試体を覆う 断熱材の厚さについては、本実験の100〜200 mmの範囲では顕著な 差が認められなかったが、調合の範囲を広げる等の実験によって、 引き続き検討する必要がある。

\section{5.まとめ}

本研究では、コンクリート円柱供試体の周囲を断熱材や型枠で 覆うことにより柱状 $\mathrm{PCa}$ 部材の各部位の温度を履歴させることを意 図したPCa部材モデル養生供試体による強度管理方法について検討 し、以下の成果を得た。

1）柱状 $\mathrm{PCa}$ 部材に存在するコア供試体を想定し、円柱供試体の側 面部を断熱材で覆い、両端面に断熱材や型枠を配置することで $\mathrm{PCa}$ 部材と同じ温度を供試体に履歴させることを意図とした $\mathrm{PCa}$ 部材モデル養生供試体 $\mathrm{S}$ 考案した。しかし、PCa柱試験体に比 べて温度下降が急であった。

2）断熱材内部に1段あたり9個の円柱供試体を2段積みに配置した $\mathrm{PCa}$ 部材モデル養生供試体Wを考案した。上部に鋼製型枠を配 置することで、上段の供試体はPCa部材の表面部コアを、下段 の供試体は中央部コアをモデル化した。PCa柱試験体よりも若 干小さな温度上昇量となったが、類似の温度履歴を示した。
3） $\mathrm{PCa}$ 部材モデル養生供試体 $\mathrm{W}$ 有用性を検証するため、実際の $\mathrm{PCa}$ 製造工場において大型PCa柱試験体との温度履歴および強度 の比較実験を行った。その結果、必ずしも大型PCa柱試験体と 同一の温度履歴および強度を示すわけではないが、大型PCa柱 試験体の中央部および表面部における温度や強度と類似した特 性を示すことが明らかになった。

4) 今後の課題も抽出されたが、PCa部材モデル養生供試体Wは柱状 $\mathrm{PCa}$ 部材の強度管理用供試体として有用になる可能性を得た。

\section{謝辞}

本稿の 2 .および 3 .に示した実験の一部については、当時宇都宮大 学大学院工学研究科に在籍していた峯竜一郎氏（現三井住友建設株 式会社）の協力を得た。また、本稿の 4 .に示したプレキャストコン クリート製造工場における検証実験については、川田建設株式会社 那須工場の道下徳隆工場長および堀池一男品質管理課長の協力を得 た。ここに記して謝意を表す。

\section{参考文献}

1）日本建築学会 : 建築工事標準仕様書・同解説 JASS 10 プレキャス卜鉄筋 コンクリート工事 $2013,2013.1$

2) 杉山央, 桝田佳寛ほか: 大断面プレキャストコンクリート部材製造時の温 度履歴特性, 日本建築学会技術報告集, 第 14 号, pp.13-18, 2001.12

3) 杉山央, 桝田佳宽ほか: 大断面プレキャストコンクリート部材の強度特性, 日本建築学会技術報告集, 第 14 号, pp.19-24, 2001.12

4) 峯竜一郎, 杉山央ほか: 各種形状・断面厚を有する高強度プレキャストコ ンクリートの強度特性に関する基礎研究, コンクリート工学年次論文集, 日本コンクリート工学会, Vol.34, No.2, pp.475-480, 2012

5) 陣内浩, 早川光敬ほか: 簡易断熱養生による高強度コンクリートの構造体 強度予測手法, 日本建築学会技術報告集, 第 11 号, pp.17-20, 2000.12

6) 劉宏涛, 浜幸雄ほか: 構造体コンクリートの温度履歴に対応した簡易断熱 養生条件の検討, 日本建築学会構造系論文集, 第 551 号, pp.7-12, 2002.1

7）立松和彦, 山崎順二ほか: 簡易断熱養生による高強度コンクリートの構 造体強度の品質管理および $\mathrm{S}$ 值, 日本建築学会技術報告集, 第 15 号, pp.11-14, 2002.6

8) 並木哲, 早川光敬ほか：簡易断熱養生による高強度コンクリートの構造 体強度推定方法, 日本建築学会大会学術講演梗概集, 材料施工, pp.977$978,2002.8$

9) 藤井和俊, 鳴瀬浩康ほか: 簡易断熱養生による中庸熱ポルトランドセメン 卜を用いた高強度コンクリートの構造体強度の推定, 日本建築学会技術報 告集, 第 16 号, pp.9-12, 2002.12

10) 藤井和俊, 鳴瀬浩康ほか: 高強度コンクリートの簡易断熱養生方法に関す る一考察, 日本建築学会技術報告集, 第 17 号, pp.11-14, 2003.6

11）中瀬博一, 藤井和俊ほか: 温度制御装置を用いた解析温度履歴養生による 高強度コンクリートの構造体強度の推定に関する研究一その 1 実大柱試験 体を用いた温度追従養生による実験一, 日本建築学会大会学術講演梗概集, 材料施工, pp.993-994, 2003.9

12）鳴瀬浩康, 藤井和俊ほか: 温度制御装置を用いた解析温度履歴養生による 高強度コンクリートの構造体強度の推定に関する研究一その 2 円柱供試体 を用いた解析温度履歴による実験一, 日本建築学会大会学術講演梗概集, 材料施工, pp.995-996, 2003.9

13）陣内浩, 黒岩秀介ほか: 設計基準強度 $150 \mathrm{~N} / \mathrm{mm}^{2}$ の高強度コンクリート の強度管理手法の検討と品質管理結果, 日本建築学会技術報告集, 第 13 巻, 第 25 号, pp.7-12, 2007.6

14）塩浜圭治, 立松和彦ほか: 実機試験結果に基づく高強度コンクリートの構 造体強度補正值 (S 值) についての一考察, 日本建築学会大会学術講演梗 概集，材料施工, pp.923-924, 2009.8

15）日本建築学会 : 高強度コンクリート施工指針・同解説, pp.65-66, 2013.11

16) 山崎学: 関東地区におけるセメント事情, コンクリート工学, 日本コンク リート工学協会, Vol.48, No.1, pp.52-56, 2010.1 


\title{
METHOD OF QUALITY CONTROL AT PRODUCTION PROCESS OF PRECAST CONCRETE COLUMN
}

\author{
Hisashi SUGIYAMA* and Kensuke MITO** \\ * Prof., Graduate School of Engineering, Utsunomiya Univ., Dr. Eng. \\ ** Graduate Student, Graduate School of Engineering, Utsunomiya Univ.
}

With the increasing number of large and high-rise reinforced concrete structures being built, there is an increasing trend toward the use of large and higher strength precast concrete members in Japan. The heat produced by the hydration of cement accumulates in the interior of large-size precast concrete members, such as a precast concrete column, causing the temperature to rise. This temperature rise affects the strength development of concrete. High-temperature curing at early ages improves early strength development of concrete, but inhibits later strength development. Accordingly, before studying the quality control at production process, a sufficient understanding of the properties of large-size precast concrete member is needed.

The strength of precast concrete is tested at production process with the test specimen made by the same curing method as an actual precast concrete member. However, the temperature history of precast concrete column with the large cross sectional size is different from that of test specimen. The difference in temperature history causes the difference of strength development between the two. The purpose of this study is to propose new types of test specimens cured under the same temperature conditions with the actual precast concrete column. The test specimens are covered with insulation and formwork according to the position in the precast concrete column.

Single-type test specimens modeled after the precast concrete column were proposed at first. The single-type specimens modeled after the middle of precast concrete column was covered entirely with insulations. The single-type specimens modeled after the surface of precast concrete column was covered with insulations and a metal formwork. However, there was a difference between the modeled specimens and the actual precast concrete column in temperature history. For instance, the rate of temperature fall of the modeled specimen after passage of maximum temperature was higher than that of the actual precast concrete column.

Subsequently, double-type test specimens modeled after the precast concrete column were proposed. The double-type test specimens were composed of two layers such as upper specimens and lower specimens. The upper specimens modeled after the surface of precast concrete column were covered with insulations, a metal formwork and the lower specimens. The lower specimens modeled after the middle of precast concrete column were covered with insulations and the upper specimens. The temperature history of upper specimen was similar to that of the surface of precast concrete column, although temperature of the specimen was slightly lower. The temperature history of lower specimen was also similar to that of the middle of precast concrete column, although temperature of the specimen was slightly lower. The strength of upper specimen was almost the same as that of the surface of precast concrete column. The strength of lower specimen was almost the same as that of the middle of precast concrete column.

According to the above results, the double-type specimens are useful as the test specimens at production process of precast concrete column. 